\title{
Analysis of Heavy Metals and Other Elements in Textile Waste Using Neutron Activation Analysis and Atomic Absorption Spectrophotometry
}

\author{
Md. Azharul Haque Chowdhury ${ }^{1 *}$, Md. Mahbubul Hoque ${ }^{2}$, Syed Mohammod \\ Hossain $^{3}$, Kamrun Naher ${ }^{4}$, Md. Amirul Islam ${ }^{4}$, Umma Tamim $^{4}$, K. M. S. Alam ${ }^{5}$ \\ and Rahat Khan ${ }^{4}$ \\ ${ }^{I}$ (Department of Environmental Science and Disaster Management, Daffodil International University, Dhaka- \\ 1207, Bangladesh) \\ ${ }^{2}$ (Department of Environmental Science and Resource Management, Mawlana Bhashani Science and \\ Technology University, Tangail-1902, Bangladesh) \\ ${ }_{3}^{3}$ (Human Resources Division, Bangladesh Atomic Energy Commission, E-12/A, Agargaon, Sher-e-Bangla \\ Nagar, Dhaka-1207, Bangladesh) \\ ${ }^{4}$ (Institute of Nuclear Science and Technology, Atomic Energy Research Establishment, Ganakbari, Savar, \\ Bangladesh) \\ 5 (Directorate of Secondary and Higher Education Bangladesh, Dhaka, Bangladesh)
}

\begin{abstract}
The work focused on the elemental and physicochemical analysis in the textile waste (Effluent and Sludge) where two effluent samples and one sludge sample were collected from Grameen Knit Dyeing Industry $(G K D I)$. Every effluent sample is divided into liquid sample ( $L 1$ and L2) and residual sample (RI and R2). Neutron Activation Analysis (NAA) method used for the elemental analysis. The study revealed that, in the sludge $(S)$ the $S b$ concentration was found $50.2 \mathrm{mg} / \mathrm{L}$ which exceeded the standard. Here Co concentration exceeded the standard. Here the highest $\mathrm{Cr}$ and $\mathrm{Cd}$ value was found in the (S) which exceeded the standard level. The total alkalinity, hardness and free $\mathrm{CO}_{2}$ level of discharged water was harmful for the environment. From this study it is revealed that the sludge contain high content of heavy metal and other harmful elements. Soda ash method can be applied to reduce the 'Cr' concentration.
\end{abstract}

Keywords- element, grameen knit dyeing, neutron, sludge, waste.

\section{INTRODUCTION}

Environmental pollution has been increasing simultaneously with increasing industrial revolution in Bangladesh. Savar industrial region is one of the largest industrial belt near Dhaka in Bangladesh. In this region there are about 100 local and foreign industries from which majority are foreign and local textiles and dyeing industries. These industries generate a huge amount of effluent every day which are being directly or indirectly discharged into the surrounding land, agricultural fields, irrigation channels and surface water which finally enter into the river. Due to such kind of environmental pollution a large number of village near to this industrial zone are being threatened ${ }^{[1]}$.

A huge amount of fresh water used for Dyeing and finishing processes in the textile sector. Textile industry contributes large quantities from the total industrial pollution because mass volume of effluents is discharged into the natural environment. Moreover effluent is generated after dyeing and finishing activities must be treated by an addition of chemical, physical and biological treatment before discharge to meet legislative requirements. Furthermore, after the dyeing processes, advanced technologies are needed, especially in order to reduce residual dyes from the effluent ${ }^{[2]}$.

Various types of Effluent treatment plants (ETP) are used in the complex industrial installations like DEPZ, Bangladesh for effluent discharge by regulatory bodies. Although we have ETP in different industries but a little amount don't know about the physicochemical properties and no stringent policies along with exercise of the effluent discharge is present in this country. The implementation of membrane technologies have been associated with most of the earlier studies depending upon the basis of laboratory, pilot scale trials and the treated water quality was assessed presently in use with the respect of process water ${ }^{[3][4]}$.

The present work has been focused on comparative investigation of elemental status of knit dyeing effluents with fabric dyeing effluents considering its socio-economic importance. Instrumental neutron activation analysis (INAA) is one of the most extensively used methods for environmental studies due to its high sensitivity, precision, versatility and multielemental character. The application of INAA technique ensures the 
production of quality baseline data as the method is treated a 'referee method' to check the accuracy of other analytical methods worldwide especially for solid sample analysis. The INAA is treated as a referee method due to the simplicity of sample preparation, capability of analysis solid sample (no chemical treatment or decomposition of sample is required like AAS, ICP-MS, etc.) simultaneous multi element determination capability, nearly matrix independent characteristics. However, as NAA involved radioactive decay turnaround time is comparatively higher than other chemical methods for long-lived elements.

Realizing the importance, an attempt has been made to perform the following studies: i) to determine the amount of lead, Cadmium, Zinc and other trace elements in the effluent and sludge sample, and ii) to see the correlation among different elements of effluent and sludge sample.

\section{MATERIALS AND METHODS}

\section{Sample Collection and Preparation}

Grameen knit dyeing industry (GKDI) has been selected for effluent and sludge sampling which is located in the Dhaka Export Processing Zone (DEPZ) new with a view to characterize the textile and dyeing effluents and sludge. Two effluent samples and one sludge sample were collected from GKDI of which one inlet (S-01), one outlet (S-02) and one sludge (GS) of the selected industry. Every effluent samples were separated into liquid and residual sample as L-1, R-1 and L-2, R-2 respectively. Effluent samples were collected in $500 \mathrm{ml}$ plastic bottles and sludge sample was collected in plastic bag from those points of industries for the analysis of physicochemical properties $(\mathrm{pH}$, temperature, transparency, EC, TDS, DO, BOD, COD, alkalinity, acidity, hardness, free $\mathrm{CO}_{2}$, TSS and TS) and elemental properties ( $\mathrm{Pb}, \mathrm{Cd}, \mathrm{Ni}, \mathrm{Cu}, \mathrm{Fe}, \mathrm{Cr}, \mathrm{Na}, \mathrm{Zn}, \mathrm{K}, \mathrm{La}, \mathrm{As}, \mathrm{Co}$ and $\mathrm{Sb}$ ). Prior to sample collection, all bottles were cleaned with dilute acid followed by distilled water. Before sampling, the bottles were rinsed again three times with the water to be sampled. About $498 \mathrm{ml}$ of water sample from each bottle was transferred to $500 \mathrm{ml}$ plastic bottle which contained $2 \mathrm{ml}$ Alkaline Potassium Iodide solution for the analysis of physic-chemical properties and $2 \mathrm{ml}$ Nitric Acid for the analysis of Heavy metal and other elements. After collection, the bottles containing samples were sealed immediately to avoid exposure to air. The samples were taken from the surface. To provide necessary information for each sample such as date of collection, location, time, etc. were recorded in the note book and each sample collected in a plastic bottle was labeled separately with a unique identification number.

The sludge sample is placed in a Petridis and taken into the oven in a temp. of $70^{\circ} \mathrm{C}$ until it is fullydried. Visible fragments were removed from the sludge sample and discarded. The sludge samples were then grinded by an agate mortar to make powder and then it is stored as stock sample. From the stock about $50 \mathrm{mg}$ sample was taken into ultra clean irradiation type polyethylene envelopes and then heat shield.

About $200 \mathrm{ml}$ waste water samples, collected from the inlet and outlet of the industries were oven dried at $80^{\circ} \mathrm{c}$ to reduce the volume 10 times in order to increase the sensitivity of the analysis. Then the samples were passed through a membrane filter paper of $0.45 \mu \mathrm{m}$ and air dried. Here the weight of the residue is measured by Eq. (1):

Residue (mg) = wt. of filter with residue - wt. of filter without residue

The filter paper with residue is assumed as a residual sample. The sample is also weighed and sealed. The remaining water in the bucknor funnel is then spiked on many folds of whatmann filter paper (No.102, 10 pcs, 12 $\times 12 \mathrm{~mm}$ ) using a micropipette and allowed to dry in the oven at $80^{\circ} \mathrm{C}$. Two water samples and two residual samples were prepared for each of the inlet and outlet sample to determine short (such as Na, K, La, As) and long lived elements (such as $\mathrm{Co}, \mathrm{Sb}, \mathrm{Fe}, \mathrm{Zn}, \mathrm{Cr}$ ). One blank sample and three solid certified reference materials (CRMs) e.g., IAEA-Soil-7, NIST-1633b (Coal Fly Ash) and IAEA-SL-1were prepared similarly for each irradiation scheme. The nuclear data table of the interested elements is shown in Table 1. The samples and the reference materials were weighted by a microbalance. Polyethylene encapsulation was performed for each water sample, blanks and relevant CRMs. Double encapsulation was performed during irradiation in Lazy Susan or dry central thimble to avoid contamination.

\section{Instruments and Instrumental Technique}

In this research different types of instruments were used for the analysis of physic-chemical parameters such as thermometer, DO bottles, Color comparator, secchidisk, DO meter (Model: 5509), digital $\mathrm{P}^{\mathrm{H}}$ meter (Model: AD 1000), TDS meter (Model: HM Digital), EC meter (Model: HANNA instruments), marker, calculator, laboratory apparatus, chemicals and plastic bottles. BOD and COD were measured by using Winkler's ideometric method. The Total hardness, alkalinity and acidity were measured following the APHAAWWA-WEF, 2005 method $^{[5]}$. Atomic absorption Spectrophotometer (A.A.S. SHIMADJU, JAPAN) used for the experiment of $\mathrm{Pb}, \mathrm{Cd}, \mathrm{Ni}$ and $\mathrm{Cu}$. Neutron Activation Analysis (NAA) method used for the determination of $\mathrm{Na}, \mathrm{K}, \mathrm{La}, \mathrm{Co}, \mathrm{Sb}, \mathrm{Fe}, \mathrm{As}, \mathrm{Cr}$, and $\mathrm{Zn}$. 
Table 1. Nuclear data table of the interested elements ${ }^{[10]}$.

\begin{tabular}{|c|c|c|c|c|}
\hline Element & Target Isotope & Nuclear Reaction & Half-life $\left(\mathrm{T}_{1 / 2}\right)$ & Gamma ray energy with intensity $(\mathrm{KeV})(\%)$ \\
\hline \multirow{2}{*}{ Sodium } & \multirow{2}{*}{${ }^{23} \mathrm{Na}$} & \multirow{2}{*}{${ }^{23} \mathrm{Na}(\mathrm{n}, \gamma){ }^{24} \mathrm{Na}$} & \multirow{2}{*}{$15.02 \mathrm{~h}$} & $1368(100)$ \\
\hline & & & & $2754.1(100)$ \\
\hline \multirow{2}{*}{ Iron } & \multirow{2}{*}{${ }^{58} \mathrm{Fe}$} & \multirow{2}{*}{${ }^{58} \mathrm{Fe}(\mathrm{n}, \gamma)^{59} \mathrm{Fe}$} & \multirow{2}{*}{$44.6 \mathrm{~d}$} & $1099.3(56)$ \\
\hline & & & & $1291.6(44)$ \\
\hline Chromium & ${ }^{51} \mathrm{Cr}$ & ${ }^{51} \mathrm{Cr}(\mathrm{n}, \gamma)^{52} \mathrm{Cr}$ & $27.71 \mathrm{~d}$ & $320.1(9.8)$ \\
\hline Zinc & ${ }^{64} \mathrm{Zn}$ & ${ }^{64} \mathrm{Zn}(\mathrm{n}, \gamma)^{65} \mathrm{Zn}$ & $243.7 \mathrm{~d}$ & $1115.5(49.8)$ \\
\hline \multirow{2}{*}{ Cobalt } & \multirow{2}{*}{${ }^{59} \mathrm{Co}$} & \multirow{2}{*}{${ }^{59} \mathrm{Co}(\mathrm{n}, \gamma){ }^{60} \mathrm{Co}$} & \multirow{2}{*}{$5.272 \mathrm{y}$} & $1173.2(99.9)$ \\
\hline & & & & $1332.5(100)$ \\
\hline \multirow[b]{2}{*}{ Antimony } & ${ }^{121} \mathrm{Sb}$ & ${ }^{121} \mathrm{Sb}(\mathrm{n}, \gamma){ }^{122} \mathrm{Sb}$ & $2.7 \mathrm{~d}$ & $564(70.6)$ \\
\hline & ${ }^{123} \mathrm{Sb}$ & ${ }^{123} \mathrm{Sb}(\mathrm{n}, \gamma){ }^{124} \mathrm{Sb}$ & $60.3 \mathrm{~d}$ & $602.7(98.1)$ \\
\hline Arsenic & ${ }^{75} \mathrm{As}$ & ${ }^{75} \mathrm{As}(\mathrm{n}, \gamma){ }^{76} \mathrm{As}$ & $26.3 \mathrm{~h}$ & $559(44.7)$ \\
\hline Potassium & ${ }^{41} \mathrm{~K}$ & ${ }^{41} \mathrm{~K}(\mathrm{n}, \gamma)^{42} \mathrm{~K}$ & $12.36 \mathrm{~h}$ & $1524(17.9)$ \\
\hline Lanthanum & ${ }^{139} \mathrm{La}$ & ${ }^{139} \mathrm{La}(\mathrm{n}, \gamma){ }^{140} \mathrm{La}$ & $40.22 \mathrm{~h}$ & $1596(95.4)$ \\
\hline
\end{tabular}

\section{Irradiation of Samples}

The samples and standards were put in an irradiation vial and made ready for irradiation. In order to measure the flux gradient within the irradiation container three IRMM Al-0.1\% Au foils were placed at the bottom, top and middle positions of the irradiation vial. The samples and standards were simultaneously irradiated using 1MW neutron beam research reactor TRIGA MARK II having neutron flux $\sim 1.52 \times 10^{13} \mathrm{n}_{\mathrm{cm}}{ }^{-2}$. Sec ${ }^{-1}$, in Dried central thimble (DCT) channel for 30 minutes at the Bangladesh Institute of Nuclear Science and Technology (INST) under the Atomic Energy Research Establishment (AERE) of Bangladesh Atomic Energy Commission (BAEC). The irradiated samples and standards were measured using two HPGe detectors with two decay intervals depending on the halflive of the interested elements.

The first counting was performed using the HPGe detector (CANBERRA, 25\% relative efficiency, 1.8 $\mathrm{keV}$ resolution at $1332 \mathrm{keV}$ of ${ }^{60} \mathrm{Co}$ ) coupled with the digital gamma spectrometry system DSPEC JR ${ }^{\mathrm{TM}}$ (ORTEC) and Maestro-32 acquisition software. The $2^{\text {nd }}$ one was performed using the HPGe detector (CANBERRA, $40 \%$ relative efficiency, $1.8 \mathrm{keV}$ resolution at $1332 \mathrm{keV}$ of ${ }^{60} \mathrm{Co}$ ) coupled with the digital gamma spectrometer DSA 1000 (CANBERRA) and Genie 2000 acquisition software.

The gamma spectrum of a sludge sample is shown in Fig 1. It have taken Eleven months (August 2013 to June 2014) to carry out the experiment, under the department of Environmental Science and Resource Management, MBSTU and Institute of Nuclear Science and Technology (INST), Atomic Energy Research Establishment (AERE) Savar.

\section{Data acquisition and analysis}

The $\gamma$-spectra acquisition for all of the irradiated samples was performed by the High Purity Germanium (HPGe) detector. In case of every irradiated samples, two independent measurement were performed by allowing various different nuclides: (1) after the decay time of 2-3 days, with a measuring time of $1.5 \mathrm{~h}$ for the determination of As, $\mathrm{Na}, \mathrm{La}$ and $\mathrm{K}$; (2) after a decay time of 3 weeksfor the determination of $\mathrm{Sb}$, $\mathrm{Zn}, \mathrm{Fe}, \mathrm{Co}$ and $\mathrm{Cr}$ with a measuring time of $2 \mathrm{~h}$. The measurements were carried out at the DCT of the detector. Binary mode was used to collect the $\gamma$-spectra which are changed into the standard ASCII mode. According to the method of Debertin and Schotzig, 1979, the summing correction for the cascading $\gamma$-rays was fulfilled; and different literatures (Frauenfelder and Steffen 1968; Morinaga and Yamazaki 1976) were used to calculate the angular correlations between cascading $\gamma$-rays ${ }^{[6][7][8]}$. By knowing the standard $\gamma$-point source's efficiencies the detection limits for the determined elements are given in Table 2.

\section{Concentration Calculation}

In the Calculation method the relative standardization approach is applied for the elemental concentration in the investigated sample using the following Eq. $(2)^{[9]}$ :

$$
\text { (W) })_{\text {Sample }}=\frac{\text { Decay corrected cps in the sample }}{\text { Decay corrected cps in the standard }} \times \text { Contents of elements in standard }
$$

Hypermet PC Version 5.1 software was used in performing the gamma peak analysis for irradiated samples and standards which was checked manually. Comparative standardization approach was used in the determination of interested element concentration ${ }^{[10][11][12]}$. 
Quality control was performed by determining elemental concentration levels in the certified reference materials NIST-1633b (Coal Fly Ash) and IAEA-SL-1 compared to IAEA-Soil7 and compared the measured values of elements with the certified ones as shown in Table 2. This ensures the reliability of analysis.

Table 2. Quality control table where reference standard was (IAEA) Soil7.

\begin{tabular}{|c|c|c|c|c|c|}
\hline Name of element & Name of std. & $\begin{array}{c}\begin{array}{c}\text { Certified value } \\
(\mathrm{ppm})\end{array} \\
\end{array}$ & $\begin{array}{c}\text { Measured } \\
\text { value }(\mathrm{ppm})\end{array}$ & Detection limit & Deviation $(\%)$ \\
\hline \multirow{2}{*}{ As (76) } & IAEA-SL-1 & 27.5 & 29.25 & \multirow{2}{*}{$0.2 \mathrm{ppm}$} & 6.38 \\
\hline & NIST-1633b & 136.2 & 125.21 & & -8.07 \\
\hline \multirow{2}{*}{$\mathrm{K}(42)$} & IAEA-SL-1 & 15000 & 12814.5 & \multirow{2}{*}{$0.02 \mathrm{wt} \%$} & -14.57 \\
\hline & NIST-1633b & 19500 & 19536.1 & & 0.19 \\
\hline \multirow{2}{*}{$\mathrm{La}(140)$} & IAEA-SL-1 & 52.6 & 48.6 & \multirow{2}{*}{$0.14 \mathrm{ppm}$} & -7.60 \\
\hline & NIST-1633b & 94 & 88.18 & & -6.18 \\
\hline \multirow{2}{*}{$\mathrm{Na}(24)$} & IAEA-SL-1 & 1720 & 1647.09 & \multirow{2}{*}{0.0003 wt $\%$} & -4.24 \\
\hline & NIST-1633b & 2010 & 2136.17 & & 6.28 \\
\hline \multirow{2}{*}{$\mathrm{Fe}(59)$} & IAEA-SL-1 & 67400 & 73265.26 & \multirow{2}{*}{$0.03 \mathrm{wt} \%$} & 8.70 \\
\hline & NIST-1633b & 77800 & 82076.8 & & 5.5 \\
\hline \multirow{2}{*}{$\mathrm{Zn}(65)$} & IAEA-SL-1 & 223 & 259.40 & \multirow{2}{*}{$0.003 \mathrm{wt} \%$} & 16.32 \\
\hline & NIST-1633b & 210 & 245.97 & & 17.13 \\
\hline \multirow{2}{*}{ Co (60) } & IAEA-SL-1 & 19.8 & 20.90 & \multirow{2}{*}{$0.3 \mathrm{ppm}$} & 5.56 \\
\hline & NIST-1633b & 50 & 53.91 & & 7.83 \\
\hline \multirow{2}{*}{$\mathrm{Sb}(122)$} & IAEA-SL-1 & 1.31 & 1.43 & \multirow{2}{*}{$0.21 \mathrm{ppm}$} & 9.86 \\
\hline & NIST-1633b & 6 & 5.71 & & -4.78 \\
\hline \multirow[t]{2}{*}{ Cr (59) } & IAEA-SL-1 & 104 & 117.74 & \multirow{2}{*}{$13.05 \mathrm{ppm}$} & 13.22 \\
\hline & NIST-1633b & 198.2 & 211.85 & & 6.89 \\
\hline
\end{tabular}

Note: NIST- National Institutes of Standards \& Technology (1533b- Coal Fly Ash), Deviations were below $10 \%$; so it quite shows that the counter was effective.

\section{Physicochemical Parameters}

\section{RESULTS AND DISCUSSION}

In this study we determined eighteen physicochemical parameters in the effluents. Among the physicochemical parameters, at first the color and odor of two effluent samples were observed. In the inlet of GKDI (S-01) the observed color and odor ware bluish and pungent respectively. But in outlet (S-02) the observed color and odor were colorless and odorless which obey the standard of ECR (1997) (Table 3) ${ }^{[13]}$. The temperature and transparency at of the sampling points recorded from $31^{\circ} \mathrm{C}$ to $39^{\circ} \mathrm{C}$ and $1 \mathrm{~cm}$ to $7.1 \mathrm{~cm}$. respectively where the temperature range is within the acceptable limit ${ }^{[13]}$. The hot water mixed with the other water bodies which lead to rise temperature of the water body. For this reason the DO content of the water will decrease which negatively affects the aquatic life ${ }^{[14]}$. These effluents should be passed through a cooling system. The water was turbid due to silt. The transparency of Mini sursagar water was found $90 \mathrm{~cm}^{[15]}$.

The $\mathrm{pH}$ values of two sampling points (S-01 and S-02) recorded 10.5 and 7.4 respectively. The $\mathrm{pH}$ value of inlet effluent sample (S-01) is higher than the acceptable limit (ECR, 1997). But the outlet sample's (S02) $\mathrm{pH}$ value is within the acceptable limit (ECR, 1997) because the ETP control the pH value by neutralization reaction. The $\mathrm{pH}$ value 9 to 11 does not permit fishes to grow slowly or reproduce ${ }^{[16]}$. The EC values recorded at two sampling points ranged from 1140 to $3280 \mu \mathrm{S} / \mathrm{cm}$ (Table 3). The highest EC value $3280 \mu \mathrm{S} / \mathrm{cm}$ was found at the Inlet of GKDI (S-01) is greater than the standard values (ECR, 1997) and the lowest at the outlet of GKDL (S-02). EC value represents that the water is not suitable for certain species of fish or microinvertebrates. TDS values at two sampling points were ranged from 1810 to $5220 \mathrm{ppm}$ (Table 3). The highest TDS value $5220 \mathrm{ppm}$ was observed at the inlet of GKDL (S-01) mostly exceeded the standard level (ECR, 1997).

Water with dissolved solids about $1000 \mathrm{ppm}$ may contains minerals that give it a distinctive taste or make it unsuitable for consumption. A TDS value of about $400 \mathrm{ppm}$ is permissible for fish production ${ }^{[17]}$. So, we can also say that the water is unsuitable for drinking, washing and domestic uses and purposes. From the investigation, it was found that values of DO at different two points ranged from 2.2 to $4.3 \mathrm{ppm}$. The lowest DO was found at the inlet (S-01) of GKDI. The DO value in inlet sample was below the acceptable limit (ECR 1997). The effluents of the textile dyes are chemical enriched. For this reason it reduced the DO of the water body. DO levels below $1 \mathrm{ppm}$ will not support fish; below $2 \mathrm{ppm}$ may lead to the death of most fishes. DO content should be above $6.0 \mathrm{ppm}$ for drinking water and more than $5.0 \mathrm{ppm}$ is suggested for fisheries, recreation and irrigation (ECR, 1997). 
Table 3. The physicochemical parameters at Grameen Knit Dyeing Industry.

\begin{tabular}{|c|c|c|c|c|}
\hline & \multicolumn{2}{|c|}{ Grameen Knit Dyeing Ind. } & \multirow{2}{*}{ Permissible limit } \\
\hline & & S-01 & $\mathrm{S}-02$ & \\
\hline \multirow{18}{*}{ 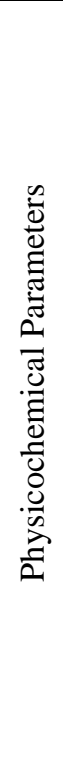 } & $\mathrm{DO}(\mathrm{mg} / \mathrm{L})$ & 2.2 & 4.3 & 4.5-8 (ECR, 1997) \\
\hline & $\mathrm{BOD}(\mathrm{mg} / \mathrm{L})$ & 225 & 120 & 250 (ECR, 1997) \\
\hline & $\mathrm{COD}(\mathrm{mg} / \mathrm{L})$ & 430 & 270 & 400 (ECR, 1997) \\
\hline & $\mathrm{pH}$ & 10.5 & 7.4 & 6-9 (ECR, 1997) \\
\hline & TDS (mg/L) & 5220 & 1810 & $2100(\mathrm{ECR}, 1997)$ \\
\hline & $\mathrm{EC}(\mu \mathrm{S} / \mathrm{cm})$ & 3280 & 1140 & 1200 (ECR, 1997) \\
\hline & Total Alkalinity (mg/L) & 644 & 504 & 200 (Patilet al. 2012) \\
\hline & Total Acidity (mg/L) & 67 & 42 & $*$ \\
\hline & Total Hardness $(\mathrm{mg} / \mathrm{L})$ & 940 & 472 & 200 (Patilet al. 2012) \\
\hline & Ca Hardness (mg/L) & 690 & 240 & $100($ WHO, 1995) \\
\hline & Mg Hardness (mg/L) & 250 & 232 & $150($ WHO, 1995) \\
\hline & Free $\mathrm{Co}_{2}(\mathrm{mg} / \mathrm{L})$ & 616 & 352 & $<50-60$ (Bhatnagar and Devi, 2013) \\
\hline & TSS (mg/L) & 40.2 & 2.1 & $5.0($ WHO, 1981) \\
\hline & $\mathrm{TS}(\mathrm{mg} / \mathrm{L})$ & 5260.2 & 1812.1 & $*$ \\
\hline & Temperature $\left({ }^{0} \mathrm{C}\right)$ & 39 & 31 & 40-45 (ECR, 1997) \\
\hline & Transparency $(\mathrm{cm})$ & 1 & 7.1 & $*$ \\
\hline & Color & Bluish & Colorless & Colorless (ECR, 1997) \\
\hline & Odor & Pungent & Odorless & Odorless (ECR, 1997) \\
\hline
\end{tabular}

* Limits not established.

BOD values of two sampling points recorded from 120 to $225 \mathrm{ppm}$ (Table 3). The BOD value of outlet was lower as $120 \mathrm{ppm}$. The GKDL wants to control the BOD values and they reduced the BOD from 225 to $120 \mathrm{ppm}$. Unpolluted waters may have BOD values of $2 \mathrm{ppm}$ or less ${ }^{[18]}$. COD values of two sampling points recorded from 270 to $430 \mathrm{ppm}$ (Table 3). The highest value of COD was found $430 \mathrm{ppm}$ in the inlet of GKDL (S-01). Because here different shifted effluents were accumulated, that is reach of different types of chemicals. In the outlet the value of COD was within the standard values. But the highest COD value in the inlet (S-01) exceeded the standard value (Table 3 ).

In these sampling points the values of Alkalinity were ranged from 504 to $644 \mathrm{mg} / \mathrm{L}$. The highest value of Alkalinity $(644 \mathrm{mg} / \mathrm{L})$ was found in the inlet (S-01). All values exceeded the standard level which will be so much harmful if it is discharged to a river or canal. Carbonate alkalinity of sewage water was recorded to be highest $0.03 \mathrm{mg} / \mathrm{L}$ and minimum $0.01 \mathrm{mg} / \mathrm{L}$. While bicarbonate alkalinity was foundat $35.60 \mathrm{mg} / \mathrm{L}$ and minimum level found at $20.15 \mathrm{mg} / \mathrm{L}$. In General, carbonate alkalinity inversely related with bicarbonate. Here bicarbonate alkalinity is the major cause of alkalinity ${ }^{[15]}$.

The total hardness values ranged from $472 \mathrm{mg} / \mathrm{L}$ to $940 \mathrm{mg} / \mathrm{L}$. The highest total hardness was found in inlet of GKDI (S-01) and the S-01 sample having total hardness values exceeding the standard values (Table $3)^{[19]}$. Hardness of water is caused due the existence of sulfate, chloride, bicarbonate, carbonate etc. ${ }^{[20]}$.

The value of free $\mathrm{CO}_{2}$ ranged from 352 to $616 \mathrm{mg} / \mathrm{L}$. The highest and lowest value was found in the inlet and outlet of GKDI. Carbon dioxide is produced from the organic carbon degradation process in aquatic ecosystem environment ${ }^{[21][22][23]}$.

The total suspended solid (TSS) is measured where the values ranged from 2.08 to 40.2. Here the highest TSS values found in the inlet (S-01) sample. It may be caused due to processing of knit and huge amount of suspended part of knit is washed away with the effluents. Higher TSS represents the higher pollution in water. Total acidity was measured from 42 to $67 \mathrm{mg} / \mathrm{L}$ where the highest value was found in the Inlet (S-01) sample (Table 3).

\section{Trace Element and Heavy Metal Concentration}

In this study we determined thirteen trace element and heavy metal concentrations in the textile wastes. The concentration of antimony at different sampling points was measured which ranging from 6.3 to $119.4 \mathrm{mg} / \mathrm{L}$. The highest and lowest concentration was found in outlet liquid (L-2) and Inlet residue (R-1) of GKDI. In the sludge (S) the concentration was found $50.2 \mathrm{mg} / \mathrm{L}$ (Table 4). The concentration of antimony in every sample exceeded the standard level $(0.15 \mathrm{mg} / \mathrm{L})$ (Table 4) (Fig 1). The concentration of lanthanum was measured in the samples of GKDI where the highest lanthanum was found in sludge (S) and lowest concentration in inlet residue (R-1). But in other sample like inlet liquid (L-1), outlet liquid (L-2) and outlet residue (R-2) the concentration was less than $0.142 \mathrm{mg} / \mathrm{L}$ (Table 4) (Fig 1). The concentration of potassium was determined in different samples of GKDI where the values ranged from less than 0.018 to 0.7 wt $\%$. Here the highest value was found in sludge sample (S) and in other samples the concentration was found less than $0.018 \mathrm{wt} \%$ (Table 4) (Fig 2). Potassium applied to soil by waste water can be taken up by plants immediately ${ }^{[24]}$. The concentration of cobalt was determined in the samples of GKDI. Where the values ranged from less than 0.264 to $51.8 \mathrm{mg} / \mathrm{L}$ and the highest value was found in sludge samples (S) (Fig 2) which exceeded the standard level $(0.05 \mathrm{mg} / \mathrm{L}$ ). Other samples (L-1, L-2, Rland R-2) having the concentration less than $0.264 \mathrm{mg} / \mathrm{L}$ (Table 4). 

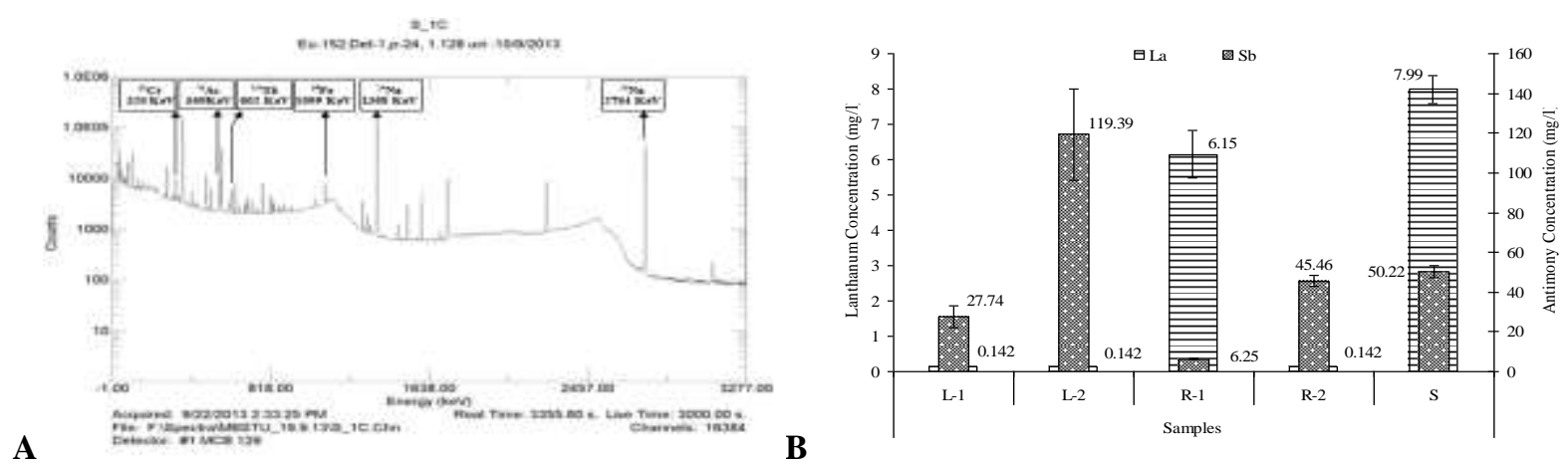

Fig 1A The gamma spectrum of a sludge sample of GKDI. B Concentration of Sb and La with uncertainty in each sample.

Table 4. The elemental concentration of the effluent and sludge of GKDI.

\begin{tabular}{|c|c|c|c|c|c|c|c|c|c|c|c|c|c|c|c|}
\hline & \multicolumn{13}{|c|}{ Trace element and heavy metal concentration } \\
\hline & & & $\mathrm{Sb}$ & $\mathrm{La}$ & $\mathrm{K}$ & Co & $\mathrm{Zn}$ & $\mathrm{Cr}$ & $\mathrm{Fe}$ & As & $\mathrm{Na}$ & $\mathrm{Pb}$ & $\mathrm{Cd}$ & $\mathrm{Cu}$ & $\mathrm{Ni}$ \\
\hline \multicolumn{3}{|c|}{ Unit } & $\mathrm{mg} / \mathrm{L}$ & $\mathrm{mg} / \mathrm{L}$ & $\mathrm{wt} \%$ & $\mathrm{mg} / \mathrm{L}$ & $\mathrm{wt} \%$ & $\mathrm{mg} / \mathrm{L}$ & $\mathrm{wt} \%$ & $\mathrm{mg} / \mathrm{L}$ & $\mathrm{wt} \%$ & $\mathrm{mg} / \mathrm{L}$ & $\mathrm{mg} / \mathrm{L}$ & $\mathrm{mg} / \mathrm{L}$ & $\mathrm{mg} / \mathrm{L}$ \\
\hline \multirow{5}{*}{ 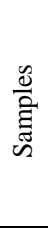 } & \multirow{2}{*}{$\bar{n}$} & L-1 & 27.74 & $<0.142$ & $<0.018$ & $<0.264$ & 0.37 & $<13.050$ & $<0.029$ & $<0.196$ & 32.30 & \multirow{2}{*}{0.035} & \multirow{2}{*}{0.005} & \multirow{2}{*}{0.02} & \multirow{2}{*}{0.001} \\
\hline & & $\mathrm{R}-1$ & 6.25 & 6.15 & $<0.018$ & $<0.264$ & 0.04 & 54.24 & $<0.029$ & $<0.196$ & 4.05 & & & & \\
\hline & \multirow{3}{*}{$\begin{array}{l}\text { í } \\
\text { in }\end{array}$} & L-2 & 119.39 & $<0.142$ & $<0.018$ & $<0.264$ & $<0.003$ & $<13.050$ & 2.06 & $|<0.196|$ & 171.65 & \multirow{2}{*}{0.024} & \multirow{2}{*}{0.007} & \multirow{2}{*}{0.025} & \multirow{2}{*}{0.02} \\
\hline & & R-2 & 45.46 & $<0.142$ & \begin{tabular}{|l|}
$<0.018$ \\
\end{tabular} & $<0.264$ & 0.04 & $<13.050$ & \begin{tabular}{|l|}
$<0.029$ \\
\end{tabular} & \begin{tabular}{|l|}
$<0.196$ \\
\end{tabular} & 28.28 & & & & \\
\hline & & Sludge & 50.2 & 8.0 & 0.8 & 51.8 & 0.10 & 204.96 & 16.9 & 3.95 & 5.21 & 0.124 & 0.098 & 0.011 & 0.71 \\
\hline \multicolumn{3}{|c|}{$\begin{array}{l}\text { Permissible limit } \\
\text { for water }\end{array}$} & $\begin{array}{c}1.0 \\
\text { (USGS) }\end{array}$ & $*$ & $\begin{array}{c}0.001 \\
\text { (WHO, } \\
2006 \text { ) }\end{array}$ & $\begin{array}{c}0.05 \\
\text { (Rowe } \\
\text { and } \\
\text { Majid, } \\
\text { 1995) }\end{array}$ & $\begin{array}{c}0.0002 \\
\text { (Ramesh } \\
\text { and } \\
\text { Yogananda } \\
\text { 2012) }\end{array}$ & $\begin{array}{c}0.10 \\
\text { (Ramesh } \\
\text { and } \\
\text { Yogananda } \\
\text { 2012) }\end{array}$ & $\begin{array}{c}0.0002 \\
\text { (ECR, } \\
1997)\end{array}$ & \begin{tabular}{|c|}
0.05 \\
$(\mathrm{ECR}$, \\
$1997)$ \\
\end{tabular} & $\begin{array}{c}60 \text { (Rowe } \\
\text { and Majid } \\
1995)\end{array}$ & \begin{tabular}{|c|}
1.0 \\
$(\mathrm{ECR}$, \\
$1997)$
\end{tabular} & $\begin{array}{c}0.01 \\
\text { (Ramesh } \\
\text { and } \\
\text { Yogananda } \\
\text { 2012) }\end{array}$ & $\begin{array}{c}0.20 \\
\text { (Ramesh } \\
\text { and } \\
\text { Yogananda } \\
\text { 2012) }\end{array}$ & $\begin{array}{c}2.0 \\
(\mathrm{ECR}, \\
1997)\end{array}$ \\
\hline \multicolumn{3}{|c|}{$\begin{array}{l}\text { Permissible limit } \\
\text { for sludge }\end{array}$} & $\begin{array}{c}0.01 \\
\text { (Lisk, } \\
1972)\end{array}$ & $*$ & $\begin{array}{c}0.001 \\
\text { (WHO, } \\
2006 \text { ) }\end{array}$ & $\begin{array}{c}0.1 \\
\text { (Rowe } \\
\text { and } \\
\text { Majid, } \\
\text { 1995) }\end{array}$ & \begin{tabular}{|c|}
0.0002 \\
(Ramesh \\
and \\
Yogananda \\
2012)
\end{tabular} & $\begin{array}{c}1.0(\mathrm{ECR}, \\
1997)\end{array}$ & $\begin{array}{c}0.0002 \\
\text { (ECR, } \\
1997)\end{array}$ & \begin{tabular}{|c|}
0.2 \\
$(\mathrm{ECR}$, \\
$1997)$
\end{tabular} & $\begin{array}{c}60 \text { (Rowe } \\
\text { and Majid } \\
1995)\end{array}$ & $*$ & $*$ & $*$ & $*$ \\
\hline
\end{tabular}

* Limits not established.

In addition we measured Zinc concentration in the samples of GKDI where the values ranged from less than 0.003 to $0.37 \mathrm{wt} \%$. Here the highest value was found in inlet liquid (L-1) and the lowest value was found in outlet liquid (L-2) (Fig 2 ) but these concentration exceeded the standard level $(0.0005 \%)$. The industries control the concentration of $\mathrm{Zn}$ in the outlet effectively (Table 4).The $\mathrm{Cr}$ concentration was determined in the samples of GKDI where the values ranged from less than 13.050 to $204.96 \mathrm{mg} / \mathrm{L}$. Here the highest value was found in the sludge sample (S) and $54.24 \mathrm{mg} / \mathrm{L}$ was found in inlet residue (R-1). Other samples having concentration less than $13.050 \mathrm{mg} / \mathrm{L}$ (Fig 2) but the concentration of $\mathrm{Cr}$ in each sample exceeded the standard level $(1.0 \mathrm{mg} / \mathrm{L})$ (Table 4). A researcher stated a method for chrome recovery using soda-ash for $\mathrm{Cr}(\mathrm{OH})_{3}$ precipitation. By using the method we can reduce the Cr concentration from the effluent in ETP ${ }^{[25]}$.

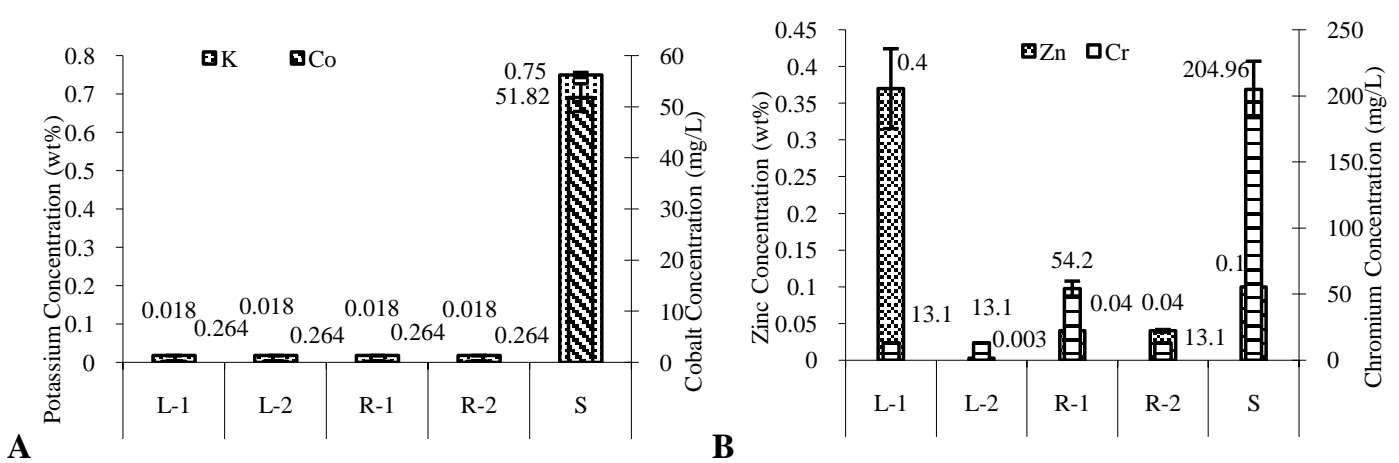

Fig 2 A Concentration of $\mathrm{K}$ and Co with uncertainty in each sample. B Concentration of $\mathrm{Zn}$ and $\mathrm{Cr}$ with uncertainty in each sample. 
Here every value exceeded the standard level $(0.0002 \%)$ (Table 2). Arsenic was measured in the samples of GKDI. Here the highest As $(3.95 \mathrm{mg} / \mathrm{L})$ was found in the sludge samples $(\mathrm{S})$. Other samples having the concentration less than $0.196 \mathrm{mg} / \mathrm{L}$ (Table 2) (Fig 3). The As concentration in each sample exceeded the acceptable limit $(0.05 \mathrm{mg} / \mathrm{L})$ (Table 4$)$. Sodium concentration was determined in the GKDI samples where the highest value (171.65 wt\%) was found in the outlet liquid (L-2) and the lowest concentration $(4.05 \mathrm{wt} \%)$ was found in Inlet residue (R-1). Inlet liquid (L-1) also having the Na concentration $32.30 \mathrm{wt} \%$ (Fig 3). The Na concentration in outlet sample exceeded the standard level (60\%) (Table 4). Various types of inorganic chemicals like sodium silicate, caustic soda, soda ash, sodium hypochlorite etc. are used in the textile industries in different operations like kiering, bleaching, washing, mercerizing etc. ${ }^{[26]}$. After neutralization reaction in the neutralization chamber those chemicals will turn into salts. That is why there is a possibility to occur the salinization of soil and alkalization of soil after mixing the effluents when it will be discharged into the surrounding area soil. Glycophytes and other types of plants cannot grow well and different seed cannot germinate on strongly alkaline soil ${ }^{[14]}$. Alkalization of soil is dominated by Na which one is a great concern like other heavy metal.

A

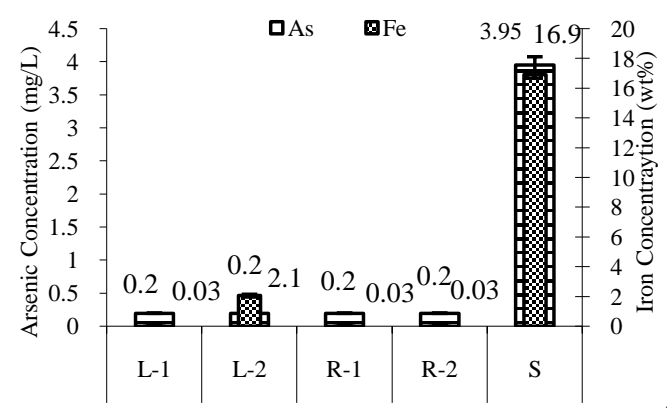

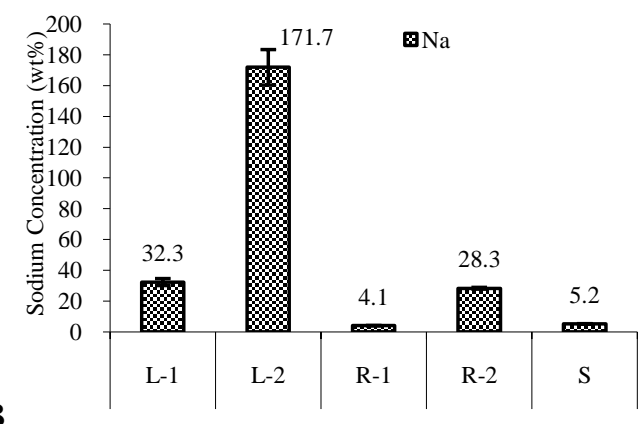

B

Fig 3 A Concentration of As and Fe with uncertainty in each sample. B Sodium concentration with uncertainty in each sample.

Lead $(\mathrm{Pb})$ concentration was also determined where the highest value $(0.124 \mathrm{ppm})$ was found in the sludge. This value is within the permissible limit. The $\mathrm{Cd}$ concentration in the sludge $(0.098 \mathrm{ppm})$ was comparatively higher than the other sampling points. But all the concentrations exceeded the standard level. Furthermore we determined the concentration of $\mathrm{Cu}$ and $\mathrm{Ni}$. The highest $\mathrm{Cu}$ and $\mathrm{Ni}$ value was found in the sludge. All the $\mathrm{Cu}$ and $\mathrm{Ni}$ concentration was within the acceptable limit. Eventually we see that here about every elemental concentration is comparatively higher in the sludge. Because sludge is the outcome of the sedimentation from the effluent. So here each of the elements may have higher amount of elemental concentration (Table 4).

\section{Correlation Among The Elements}

The degree of relationship between value of $\mathrm{Sb}$ and $\mathrm{La}$ of the waste samples depicted that the value of $\mathrm{Sb}$ is decreasing with the increasing of La value. It is a negative relationship where the regression coefficient is $\mathrm{r}$ $=0.105$ and the regression equation is $\mathrm{y}=-2.897 \mathrm{x}+58.50$ (Table 5). There is also a negative relationship between $\mathrm{Sb}$ and $\mathrm{Na}$ where the $\mathrm{r}=0.011$ and the regression equation is $\mathrm{y}=-2.897 \mathrm{x}+58.50$ (Fig 4).

Table 5. Correlation among different elements in effluent and sludge.

\begin{tabular}{|c|c|c|c|c|c|c|c|c|c|}
\hline Parameters & $\mathrm{Sb}$ & $\mathrm{La}$ & $\mathrm{K}$ & Co & $\mathrm{Zn}$ & $\mathrm{Cr}$ & $\mathrm{Fe}$ & As & $\mathrm{Na}$ \\
\hline $\mathrm{Sb}$ & 1 & & & & & & & & \\
\hline $\mathrm{La}$ & $-0.394^{\mathrm{NS}}$ & 1 & & & & & & & \\
\hline $\mathrm{K}$ & $0.005^{\mathrm{NS}}$ & $0.737^{\mathrm{NS}}$ & 1 & & & & & & \\
\hline Co & $0.005^{\mathrm{NS}}$ & $0.737^{\text {NS }}$ & $1.000^{* *}$ & 1 & & & & & \\
\hline $\mathrm{Zn}$ & $-0.387^{\mathrm{NS}}$ & $-0.221^{\mathrm{NS}}$ & $-0.040^{\mathrm{NS}}$ & $-0.040^{\mathrm{NS}}$ & 1 & & & & \\
\hline $\mathrm{Cr}$ & $-0.121^{\mathrm{NS}}$ & $0.865^{\mathrm{NS}}$ & $0.977^{* *}$ & $0.977^{* *}$ & $-0.100^{\mathrm{NS}}$ & 1 & & & \\
\hline $\mathrm{Fe}$ & $0.118^{\mathrm{NS}}$ & $0.705^{\mathrm{NS}}$ & $0.993^{* *}$ & $0.993^{* *}$ & $-0.090^{\mathrm{NS}}$ & $0.961^{* *}$ & 1 & & \\
\hline As & $0.005^{\mathrm{NS}}$ & $0.737^{\mathrm{NS}}$ & $1.000^{* *}$ & $1.000^{* * *}$ & $-0.040^{\mathrm{NS}}$ & $0.977^{* *}$ & $\mathrm{0.993}^{* *}$ & 1 & \\
\hline $\mathrm{Na}$ & $0.915^{*}$ & $-0.559^{\mathrm{NS}}$ & $-0.343^{\mathrm{NS}}$ & $-0.343^{\mathrm{NS}}$ & $-0.297^{\mathrm{NS}}$ & $-0.432^{\mathrm{NS}}$ & $-0.230^{\mathrm{NS}}$ & $-0.343^{\mathrm{NS}}$ & 1 \\
\hline
\end{tabular}

Legend: $* *=$ Significant at 0.01 level; $*=$ Significant at 0.05 level; ${ }^{\text {SS }}=$ Not significant.

The values of $\mathrm{Cr}$ increasing with the increasing of $\mathrm{Na}$ which exhibited a strong positive relationship between them where the $r=0.730$ and the regression equation $y=40.99 x-71.13$. It is found from this correlation that any $\mathrm{Cr}$ rich sample may also contaminated with $\mathrm{Na}$ and have high content of salt (Fig 4). 

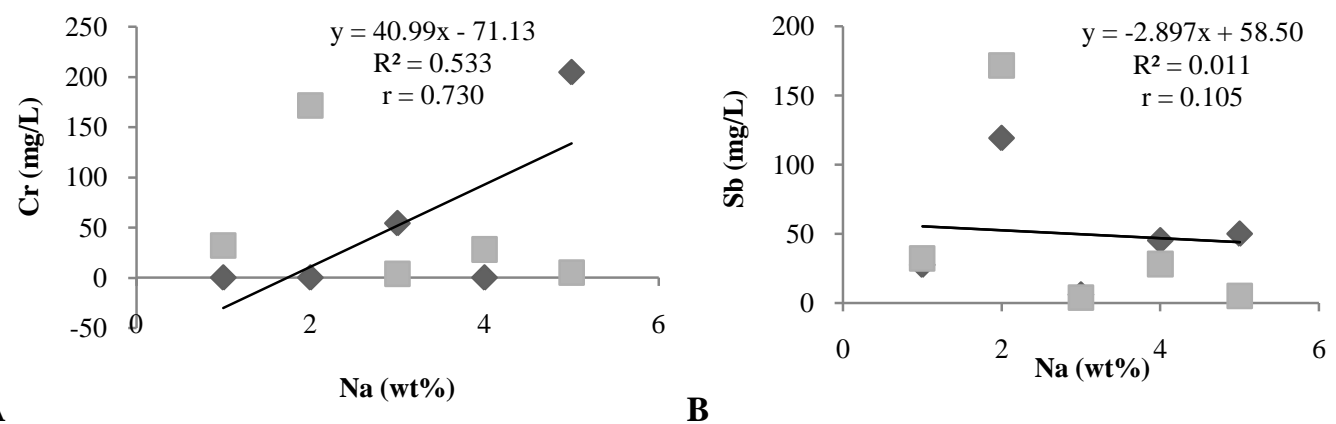

B

Fig 4 A Correlation between $\mathrm{Cr}$ and $\mathrm{Na}$. B Correlation between $\mathrm{Sb}$ and $\mathrm{Na}$.

Pearson's correlation shows relation among the parameters of textile wastes. We did not find any values for some parameters. For those elements we used the detection limit as a value to easily see the correlation among those elements. Here we can see there is strong positive correlation between ' $\mathrm{K}$ ' with (Co, $\mathrm{Cr}$, Fe and As); 'Co' with (Cr, Fe and $\mathrm{As}$ ) and 'Cr' with (Fe and As); 'As' with Fe at $1 \%$ significant level respectively. Here only one positive correlation found between ' $\mathrm{Sb}$ ' with $\mathrm{Na}$ at $5 \%$ significant level. We found from this study that there are some negative correlations among parameters, those are not significant (Table 5).

Moreover there is also a correlation found between $\mathrm{Na}$ and $\mathrm{Fe}$ and it is a positive relationship. Here the $\mathrm{r}=0.68$ and the regression equation $\mathrm{y}=3.178 \mathrm{x}-5.738$. It denotes that any sample having $\mathrm{Fe}$ also may have $\mathrm{Na}$ content (Table 5). We found also a negative relation between $\mathrm{Na}$ and $\mathrm{Zn}$. Here the $\mathrm{r}=0.445$ and the regression equation is $\mathrm{y}=-19.75 \mathrm{x}+107.5$. From this relation it is depicted that increasing $\mathrm{Zn}$ concentration, $\mathrm{Na}$ concentration decrease. It denotes that any $\mathrm{Zn}$ rich sample may have less concentration of Na (Fig 5). There is also a positive correlation found between $\mathrm{Na}$ and As where $\mathrm{r}=0.707$. Eventually from this correlation it is assumed that if any sample has $\mathrm{Na}$ it can also contain As concentration (Table 5). Furthermore we see the value of $\mathrm{Co}$ is increasing with the increasing of As and there was a strong positive relationship between them where the $r=0.707$ and the regression equation is $y=10.36 x-20.72$. From this correlation it is assumed that any As rich sample may also have high content of Co (Fig 5). This Correlation may applicable for the textile effluent and sludge. For other types of sample it may vary which will depend upon the ingredients used in the production process. $\mathrm{Na}$ has a positive correlation with $\mathrm{Cr}$ because Sodium Chromate $\mathrm{Na}_{2} \mathrm{CrO}_{4}$ is a dyeing auxiliary in the textile industry ${ }^{[27]}$. For this reason we can say that $\mathrm{Na}$ and $\mathrm{Cr}$ both have a positive correlation. Na has a positive correlation with As because Sodium Arsenate $\left(\mathrm{NaAsO}_{2}\right)$ is used as both dyeing agent and drying agent in the textile industry ${ }^{[28][29]}$.
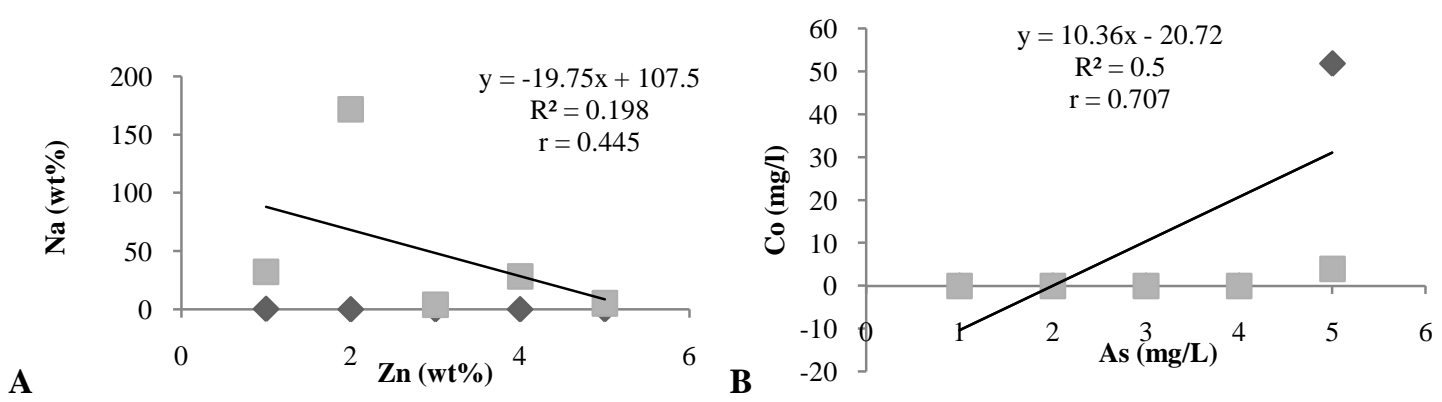

Fig 5 A Correlation between $\mathrm{Na}$ and $\mathrm{Zn}$. B Correlation between Co and As.

$\mathrm{Na}$ has a positive relation with Fe because Sodium Ferrocyanide $\mathrm{Na}_{4}\left[\mathrm{Fe}(\mathrm{CN})_{6}\right]$ is a chemical additive known as E 535 in the EU. It is added to road and food grade salt as an anticaking agent ${ }^{[30]}$. When combined with iron, it converts to a deep blue pigment called Prussian blue ${ }^{[31]}$. It is used for bleaching, toning, and fixing. Without these reason we can say that $\mathrm{Na}$ rich compounds are widely used in the textile dyeing industry as sodium Hypochlorate, or Soda Ash etc. The Fe concentration is found at a high rate in the ground water in the northern part of Bangladesh ${ }^{[32]}$. The textile industry uses a large amount of ground water. That is why there is a possibility to get a high rate of $\mathrm{Na}$ as well as $\mathrm{Fe}$. 
From all of these correlations eventually it is seemed that Na has a positive correlation with As, Fe and Cr. So we can apply The Higgins Loop ion exchange system using DOWEX G-26 resin to reduce the Na concentration by which the possibility of remaining of As, Fe and Cr will decrease ${ }^{[33]}$. Because As and Cr both have many detrimental effects on the environment ${ }^{[34]}$.

\section{CONCLUSION AND RECOMMENDATION}

From this study it is clear that GKDI has effluent treatment opportunity but the level of effluent treatment is not adequate. It is also found that the sludge having a large level of heavy metal content which is damped to the surrounding area is very dangerous for the environment and human being as well. We observed the NAA method is most applicable method for these kinds of elemental tests where the uncertainty can be measured and quality control is ensured. From all of these correlations eventually it is seemed that Na has a positive correlation with As, Fe and Cr. In addition our result of this study suggest that the Higgins Loop ion exchange system using DOWEX G-26 resin is needed to reduce the Na concentration by which the possibility of remaining of $\mathrm{As}, \mathrm{Fe}$ and $\mathrm{Cr}$ will decrease; reverse osmosis and charcoal method can be applied to decolorize the discharged effluents; soda ash method can be used to reduce $\mathrm{Cr}$ concentration; the sludge should be treated in advanced scientific method before dumping; and proper monitoring by the environmental auditors should be developed.

\section{ACKNOWLEDGEMENT}

The authors are very much grateful to the authority of the Institution of Nuclear Science and Technology, Atomic Energy Research Establishment, Savar, Dhaka; Bangladesh for their kind cooperation.

\section{REFERENCE}

[1]. M.S. Sultana, M.M. Rahman, A.K.M.R. Alam, A.H.M. Saadat, and M.J. Uddin, Analysis of some trace elements in the uncultivated soils of Savar by ICPMS, Bangladesh Journal of Environmental Science, 1, 2003, 57- 62.

[2]. K. Kestioglu, and M. Yalili, Treatability of Textile Industry Wastewater with High COD Content by Chemical- Precipitation and Adsorption, Ecology Journal, 15(59), 2006, 27-31

[3]. C. Tang, and V. Chen, Nano filtration of textile wastewater for water reuse, Desalination, 143(1), 2002, 11-20

[4]. M. Marcucci, G. Ciardelli, A. Matteucci, L. Ranieri, and M. Russo, Experimental campaigns on textile waste water for reuse by means of different membrane processes, Desalination, 149(3), 2002, 137-143.

[5]. APHA-AWWA-WEF, Standard Methods for the Examination of Water and Wastewater. (20 ${ }^{\text {th }}$ Ed.) (USA:Washington DC. American Public Health Association, 2005).

[6]. K. Debertin, and U.Schotzig, Coincidence summing corrections in Ge(Li)-spectroscopy at low source-detector distances, Nuclear Instruments and Methods, 158, 1979, 471

[7]. H. Frauenfelder, and R.M. Steffen, Angular correlations. In K. Siegbahn (Ed.) Alpha, beta and gamma ray spectroscopy (2 ${ }^{\text {nd }}$ Ed.). (North-Holland: Amsterdam, 1968) 997-1198.

[8]. H. Morinaga, and T. Yamazaki, In-beam gamma ray spectroscopy, (North-Holland: Amsterdam Publishing Company, 1976) 81-103.

[9]. M.S. Rahman, S.M. Hossain, and M.J. Uddin, Investigation of Vertical Distribution of Soil Elements at Central Part of Bangladesh Using Neutron Activation Analysis, International Journal of Environmental Protection, 3(2), 2013, 5-13.

[10]. S.J. Parry, Activation Spectrometry in Chemical Analysis, Chemical Analysis (119 ${ }^{\text {th }}$ Ed.) (New York: John Wiley and Sons., 1991)48, $68-69,86$.

[11]. T. Bereznai, Methods, Problems and Trends of Standardization in Multi-element Reactor Neutron Activation Analysis, Fresenius Journal of Analytical Chemistry, 302, 1980, 353-363.

[12]. C.M. Ryan, C.M. Marianno, W.S. Charlton, and W.D. James, Neutron Activation Analysis of Concrete for Cross-border Nuclear Security, Journal of Radioanalytical and Nuclear Chemistry, 291, 2012, 267-272.

[13]. ECR. (Environmental Conservation Rules), Gazette Notification, (Bangladesh: Ministry of Environment and Forests,1997).

[14]. S.S. Dara, A Textbook of Environmental Chemistry and Pollution Control (7 ${ }^{\text {th }}$ Ed.), (India: S. Chand \& company Ltd.,1993) 280-281.

[15]. M. Vikas, B. Daulal, and Bahura, Study of Physico-Chemical Parameters of Wastewater of Various Regions of Bikaner City, Rajasthan, Journal of Chemical, Biological and Physical Sciences, 3(1), 2013, 588-592.

[16]. M.R.H. Sarker, A. Razzaque, M.M. Hoque, S. Roy, and M.K. Hossain, Investigation of Effluent Quality from an Effluent Treatment Plant of a Textile Industry, Fakir Knitwear Ltd, Narayangonj, Bangladesh. J. Environ. Sci. and Natural Resource,8(2),2015, 25-31.

[17]. G.R. Chhatwal, Encyclopedia of Environmental biology ( $2^{\text {nd }}$ Ed.) (New Delhi, India:Animal Publications Pvt. Ltd., 1998) 287-301.

[18]. A.S.M. Saifullah, M.H. Kabir, A. Khatun, S. Roy, and M.S. Sheikh, Investigation of Some Water Quality Parameters of the Buriganga River, J. Envrion. Sci. and Natural Resource, 5(2), 2012, 47-42.

[19]. P.N. Patil, D.V. Sawant, and R.N. Deshmukh, Physico-chemical parameters for testing of water-A review, International Journal of Environmental Sciences, 3(3),2012, 1194-1207.

[20]. A.K.M.L. Rahman, M. Islam, M.Z. Hossain, and M.A. Ahsan, Study of the seasonal variations in Turag river water quality parameters, African Journal of Pure and Applied Chemistry, 6(10), 2012, 144-148.

[21]. S.V. Smith, and J.T. Hollibaugh, Annual cycle and interannual variability of ecosystem metabolism in a temperate climate embayment, Ecology/Ecological Monographs, 67, 1997, 509.

[22]. S.V. Smith, and J.T. Hollibaugh, Coastal metabolism and the oceanic organic carbon balance, Reviews of Geophysics,31, 1993, 7576.

[23]. C.S. Hopkinson, Shallow-water and pelagic metabolism: Evidence of heterotrophy in the near-shore Georgia Bight, Marine Biology, 87, 1985, 19.

[24]. G.J. Levy, and J.R. Torrento, Clay dispersion and macroaggregate stability as affected by exchangeable potassium and sodium, Soil Science, 160 (5), 1995,352-358.

[25]. S. Wolstenholme, The Tannery Effluent Problem-Practical Waste Treatment and Disposal (Ed.) (Denis Dickinson: Applied Science Publisher, 1974). 
[26]. A.E. Ghaly, R. Ananthashankar, M. Alhattab, and V.V. Ramakrishnan, Production, Characterization and Treatment of Textile Effluents: A Critical Review, J. Chem. Eng. Process Techol, 5, 2014, 182.

[27]. G. Anger, J. Halstenberg, K. Hochgeschwender, C. Scherhag, U. Korallus, H. Knopf, P. Schmidt, and M. Ohlinger, Chromium Compounds, Ullmann's Encyclopedia of Industrial Chemistry (Weinheim: Wiley-VC E H.homework, 2005) Available at: https://en.wikipedia.org/wiki/Sodium_chromate\#Uses. Accessed: June 01, 2016.

[28]. G.D.Considine, Van Nostrand'sEncylcopedia of Chemistry (14 ${ }^{\text {th }}$ Ed.),(Hoboken,NJ: Wiley-Interscience, 2005). Available at: https://en.wikipedia.org/wiki/Sodium_arsenite. Accessed: June 01, 2016.

[29]. J.M. Stellman, Encyclopedia of Occupational Health and Safety ( $4^{\text {th }}$ Ed.) (Geneva: International labor office, 1998$) 5$.

[30]. WHO, (World Health Organization), Toxicological evaluation of some food additives including anticaking agents, antimicrobials, antioxidants, emulsifiers and thickening agents, Geneva, (1974) Accessed: 18 May 2009.

[31]. Encyclopedia Britannica, Prussian blue, 2009. Available at: http://www.britannica.com/search?query=prussian+blue.Accessed: 18 May, 2009.

[32]. D. Hossain, M.S. Islam, N. Sultana, and T.R. Tusher, Assessment of Iron Contamination in Groundwater at Tangail Municipality, Bangladesh, J. Environ. Sci. \& Natural Resources, 6(1), 2013, $117-121$.

[33]. DCC, (Dow Chemical Company), A Low Cost Option to Reduce Sodium Levels in Coal Bed Methane Coproduced Wastewater using DOWEX G-26 Resin, DOWEX Ion Exchange Resins. 2014.

[34]. A.K. De, Environmental Chemistry (6 $6^{\text {th }}$ Ed.), (India: New Age International Pvt. Ltd. Publishers, 2008) 87-200.

[35]. A. Bhatnagar, and P. Devi, Water quality guidelines for the management of pond fish culture, International Journal of Environmental Sciences, 3(6),2013, 1980-2009.

[36]. Banglapedia, Bangladesh Asiatic Society(National Encyclopedia of Bangladesh,2010) Available at: http://maps-ofbangladesh.blogspot.com/2010/12/political-map-of-savar-upazila.html. Accessed: June 01, 2016.

[37]. D.J. Lisk, Trace metals in soils, plants, and animals, (New York: Academic Press, 1972) 450.

[38]. D.R. Rowe, and I.M.A. Magid, Handbook of wastewater Reclamation and Reuse, (India: CRC Press. Inc., 1995$) 550$.

[39]. H.L. Ramesh, and M.V.N. Yogananda, Assessment of Heavy Metal Contamination in Green Leafy Vegetables Grown in Bangalore Urban District of Karnataka, Advances in Life Science and Technology, 6,2012, 51.

[40]. USGS. (United States Geological Survey),Mineral Commodity Profiles, Antimony, 2003. Available at: https://pubs.usgs.gov/of/2003/of03-019/of03-019.pdf. Accessed: 01 June, 2016.

[41]. WHO, (World Health Organization), Guidelines for Drinking Water Quality Recommendations,(Switzerland: Geneva,1981).

[42]. WHO, (World Health Organization), Guidelines for Drinking Water Quality Recommendations.(3 ${ }^{\text {rd }}$ Ed.)(Switzerland: Geneva, 2006)1.

[43]. WHO, (World Health Organization), Guideline for Drinking Water Quality,(Switzerland: Geneva, 1995). 